Электронный научный журнал (Online). ISSN 2303-9922. http://www.vestospu.ru

УДК 94(47)“1917”

DOI: $10.32516 / 2303-9922.2019 .32 .12$

\title{
А. А. Сepыx
}

\section{Прошлое и настоящее в революционной повседневности М. М. Богословского (по материалам дневника историка)}

В статье проведен анализ дневниковых записей профессора Московского императорского университета М. М. Богословского за 1917 г. Поставлено под сомнение понятие «внутренняя эмиграция» в отношении стратегии его поведения. Определены особенности восприятия Богословским революционной повседневности 1917 г. сквозь призму профессионального опыта историка. Выявлены исторические события отечественной и мировой истории, которые, по его мнению, являются маркерами, определяющими характер революционных трансформаций 1917 г. Сделан вывод о том, что профессиональный, исторический взгляд М. М. Богословского на революцию 1917 г. позволил ему включить революционные события в контекст мировой и отечественной истории и поставить их в один ряд с событиями Смутного времени в России, а также с Английской и Французской революциями. Именно через сравнение революции 1917 г. со значимыми историческими событиями историк на страницах дневника приходит к пессимистическим прогнозам о будущем Российского государства. Через анализ дневниковых записей автор статьи раскрыл значение для Богословского идеи преемственной связи между опытом жизнедеятельности людей в прошлом и настоящем, так как именно исторический опыт, по его мнению, является связующим звеном истории.

Ключевые слова: дневниковые записи, М. М. Богословский, «внутренняя эмиграция», Российская империя, революция 1917 года.

В первой четверти XX века в российском обществе происходила переоценка существующих ценностей и определение новых целей и ориентиров. Историки конца XIX начала XX столетия невольно стали свидетелями и участниками социокультурных изменений общества. Научное сообщество историков, являясь частью общества, принимало участие в социокультурных трансформациях начала века. При этом эта группа имела специфические профессиональные навыки, которые позволили им выбрать наиболее правильные, по их мнению, стратегии индивидуального выхода из сложившейся кризисной ситуации.

Историки рубежа XIX-XX веков подошли к событиям революции 1917 г. со сложившимися мировоззренческими и профессиональными представлениями. Они стали «учителями» для молодого поколения преемников, которым транслировали профессиональные знания и традиции научных школ.

При всем многообразии индивидуальных поведенческих стратегий представителей интеллигенции и научного сообщества в современной исторической науке обычно выделяют три основных модели поведения, характерных для представителей старшего поколения интеллектуальной отечественной элиты в период революции 1917 г. и становления советского государства. Выбор каждой из моделей был обусловлен как субъективными, так и объективными причинами. Первая модель - эмиграция. Согласимся с мнением А. С. Ахиезера о том, что эмиграция как процесс свободного передвижения является нетипичным вариантом поведения в русской истории $[1$, с. 70$]$. Однако в первой четверти $\mathrm{XX}$ века в России наблюдалось несколько волн эмиграции. За рубежом оказались одни из самых значимых представителей отечественной исторической науки этого периода А. А. Кизеветтер, П. Н. Милюков, Е. Ф. Шмурло и др. По некоторым данным, в эмиграции после 1922 г. находилось около 500 ученых [12, с. 199].

Подробно их жизнь и деятельность описывали сами историки в воспоминаниях, письмах и дневниковых записях. Для публикации воспоминаний было основано несколь-

(C) Серых А. А., 2019 
Электронный научный журнал (Online). ISSN 2303-9922. http://www.vestospu.ru

ко серийных изданий. Наиболее значимые из них «Архив русской истории», журналы «На чужой стороне» и «Историк и современник». Отметим лишь тот факт, что, находясь в вынужденной эмиграции, историки делали все возможное для сохранения нормальной повседневной жизнедеятельности. Наиболее активно деятельность академических групп проявилась в Праге, где благодаря «Русской акции» был создан Русский университет и несколько исследовательских учреждений. Среди наиболее известных отечественных историков «старшего поколения», работавших в Праге, отметим А. А. Кизеветтера, Е. Ф. Шмурло и Г. В. Вернадского до его эмиграции в США.

Второй вариант поведения - принятие новой социокультурной структуры и активное включение в жизнедеятельность «нового» государства и общества. Самым ярким примером подобного поведения из последнего поколения дореволюционных историков, на наш взгляд, является М. Н. Покровский. Он - один из немногих представителей старшего поколения научного сообщества, кто воспринял идеи марксизма и стал активным критиком «старой», или «буржуазной», научной школы. Оценки, которые Покровский давал коллегам, отличались особой резкостью. Его влияние было столь значительным еще и потому, что он обладал практически монопольным правом в решении задач подготовки молодых кадров историков-марксистов.

И третий вариант поведения - это та модель, которую Л. А. Сидорова вслед за С. П. Мельгуновым назвала «внутренней эмиграцией» [14]. Замыкание в себе, расстановка четких границ между собой и «окружающей действительностью» после 1917 г. становятся для историков распространенной моделью поведения. Однако подобного рода абсолютизация также является неточной. Понятие «внутренняя эмиграция» предполагает, что субъект определяет для себя перечень так называемых «внешних событий», которые происходят в реальности, но от которых человек отстраняется или игнорирует их. Согласимся с О. В. Воробьевой в том, что сам термин «внешние события» неточен. Если события каким-то образом (через практику или информацию) доходят до человека, значит они уже являются внутренними: «Все, в чем человек присутствует - событие внутреннее, становящееся поводом к собственному внутреннему содержанию, накладывающее отпечаток на работу мысли и сознания» [4, с. 389]. Избегание определенных событий или ситуаций, принципиальное неучастие в них - это тоже реакция на происходящие процессы, даже, может быть, более яркая.

Парадокс социокультурной ситуации 1917 г. заключается в том, что, несмотря на революцию, а точнее благодаря ей, те историки, которые остались, в контексте «новой России» с профессиональной точки зрения получили даже больше. Владение «ремеслом историка» позволило им рассматривать происходящие процессы в исторической перспективе. Во время событий 1917 г. и сразу после них, в период становления советского государства, они имели уникальную возможность сопоставлять прошлое и настоящее, «оживить» историю, которую старались транслировать новому поколению молодых исследователей, однако насколько те были восприимчивы к этому, зависело не только от самих историков. Например, М. В. Нечкина, работая над биографией В. О. Ключевского, обращалась за консультацией к М. М. Богословскому, рекомендации которого впоследствии нашли отражение в итоговом варианте текста.

М. М. Богословский оказал значительное влияние на формирование первого поколения «советских историков», передавая им традиции, морально-нравственные и профессиональные нормы дореволюционной исторической школы. Однако жизнь и деятельность самого Михаила Михайловича долгое время оставались вне исследовательского поля. 
Электронный научный журнал (Online). ISSN 2303-9922. http://www.vestospu.ru

Первым обратился к изучению его наследия Л. В. Черепнин в 1974 г. Академик активно использовал архивные материалы и отрывки из дневниковых записей [21]. Позднее тексты М. М. Богословского стали предметом изучения Л. А. Черной, исследователь подготовила вступительную статью к сборнику его избранных сочинений [2]. Педагогическая деятельность историка привлекла внимание Т. И. Халиной [19; 20]. Ключевым исследователем биографии и творчества Богословского в настоящее время является А. В. Мельников. Им составлен список печатных трудов М. М. Богословского [15], выявлена цензурная правка при издании в 1940-1948 гг. биографии Петра I, над которой трудился Богословский, существенное внимание уделено научным трудам, рецензиям историка, эпистолярному наследию, а также воспоминаниям о нем коллег и близких людей [7-9].

К исследованию дневниковых записей М. М. Богословского обратились Е. В. Неберекутина, Т. В. Сафронова [10; 11] и А. Е. Иванов [5]. Ряд статей С. О. Шмидта включает в себя весь спектр вопросов, касающихся не только биографии и творчества М. М. Богословского, но и социокультурного контекста первой четверти XX века [22-24]. С. О. Шмидт выявляет основные тематические блоки дневниковых записей и высказывает мысль о необходимости дальнейшего анализа этого исторического источника, поскольку он остается актуальным не только для изучения биографии самого Богословского, но и для исследования научного сообщества в целом в условиях социокультурного кризиса. К вопросам отражения революционной повседневности на страницах дневника Богословского обращались П. С. Кабытов и Е. П. Баринова [6]. Анализ дневниковых записей историка позволил им выявить отдельные моменты, характеризующие самоанализ Богословского в период работы над биографией Петра I.

Отметим, что для всех исторических работ, посвященных М. М. Богословскому, характерен комплексный подход к изучению его личности. Исследователи жизни, творчества и эпистолярного наследия Михаила Михайловича, как правило, включали его в контекст российской действительности конца XIX — начала XX века и уже через него рассматривали особенности профессиональной деятельности. Наша задача состоит в обратном. Цель исследования - раскрыть специфику восприятия Богословским революционной повседневности 1917 г. сквозь призму профессионального опыта, а также выявить аналогии с событиями мировой истории, которые, по его мнению, являются актуальными в социокультурном контексте 1917 г.

В одной из работ Л. А. Сидорова предполагает, что ощущение «внутренней эмиграции» было присуще большинству историков «старой школы», оставшихся в Советской России, такая позиция позволяла им поставить четкую границу между своими «старыми» духовными идеалами и принципами «новой» реальности [13, с. 170]. На наш взгляд, эта мысль требует ряда уточнений. Мы не можем утверждать, что поведение М. М. Богословского, не покинувшего страну, стало типичным примером «внутренней эмиграции». Напротив, его поведение можно охарактеризовать как «мирное сосуществование» с советской властью. Богословский при всей его «закрытости» - яркий пример ученого, живущего историей, а события, связанные с революцией, являлись для него глубоко личностными.

Дневники - специфический исторический источник. Дневниковые записи отличаются краткостью временного промежутка между событием, которое каким-то образом затронуло автора, и его трактовкой в тексте. Дневник, как правило, отражает представления автора о каких-либо событиях или процессах в настоящий момент, раскрывает его саморефлексию и попытку найти «свое место в мире». С другой стороны, исходя из текста источника, мы можем предполагать, что М. М. Богословский писал дневники не столько для себя, сколько для будущего. Обращает на себя внимание тот факт, что в тек- 
Электронный научный журнал (Online). ISSN 2303-9922. http://www.vestospu.ru

сте дневника Богословский обращался к сыну: «Милый мой Каплюшечка, если будешь когда-нибудь читать эти строки, вспомни, как я любил тебя!» [3, с. 109]. Более того, С. О. Шмидт отмечал, что в текст дневника Богословский не раз вносил правки, особенно в строки, отражающие его отношение к происходящим событиям, что, по мнению академика, «обуславливает еще большее доверие к дневниковым записям» [24, с. 13].

М. М. Богословский встретил революционный 1917 г. в возрасте 50 лет в звании ординарного профессора Московской духовной академии и Московского университета, в котором он возглавлял кафедру русской истории. В 1911 г. Михаил Михайлович стал преемником В. О. Ключевского. Десятилетие перед революцией стало зенитом научной и педагогической деятельности историка. В 1910-х гг. Богословский приступает к написанию подробной биографии Петра I, выходят лекционные курсы по истории России XVIII-XIX вв., прочитанные на Московских высших женских курсах и в Московском университете, учебник русской истории для IV класса гимназий, затем издается учебник для V класса [15].

В этот период М. М. Богословский, как и многие выдающиеся историки его поколения, проходит этап внутреннего становления как «учителя» и «авторитета» для студентов, молодых ученых, будущих представителей поколения «красной профессуры».

Михаил Михайлович делал дневниковые записи регулярно, в настоящий момент они опубликованы за 1913, 1916-1917 и 1919 гг. Однако материалы дневника за 1917 год отличаются особой эмоциональностью, детальностью и скрупулезностью изложения, в течение этого года историк вел записи практически ежедневно.

Уже 4 января 1917 г. М. М. Богословский делает первую запись, в которой вписывает происходящие события в контекст мировой истории: «Происходит нечто подобное тому, что Англия переживала во второй четверти XVII в., когда все общество было охвачено религиозной манией. С тою разницей, что у нас мания политическая» [3, с. 288]. Оценивая происходящие события в контексте, Богословский приходит к выводу о «наивности» российского общества и «близорукости взоров в будущее», а отсюда к непониманию общественностью мысли о том, что российская революция схожа с английской или французской революциями только внешне: «Не понимают, что революции в цивилизованных странах проходят по-цивилизованному < ..> А ведь у нас политическая революция, как в 1905 , повлечет за собой экспроприации, разбои и грабежи, потому что мы еще не цивилизованная страна, а казацкий круг Разина или Пугачева» [3, с. 288]. Эмоциональность текста, написанного историком, говорит о его неравнодушии. Основываясь на цитате, нельзя обвинять историка в нелюбви к стране или в осуждающем отношении к российскому обществу. Напротив, здесь проявляется эмпатия и беспокойство за будущее страны.

Подобные мысли о «наивности» и некоторой «необразованности» основной массы российского общества, а одновременно и отсылка к Понтию Пилату, которая возникает, вероятнее всего, непроизвольно, встречается в текстах дневника и в начале февраля. М. М. Богословский писал об общественном обвинении царя во всех текущих социально-экономических проблемах: «Общий вопль “Распни! Распни его!”; в этом вопле только слепое чувство раздражения и столь же мало сознания и разума, как и тогда перед Пилатом. Толпа коллективно чувствовать может, а рассуждать - нет» [3, с. 304]. Уникальность положения М. М. Богословского, как и других состоявшихся историков того времени, заключается в способности найти общие черты в событиях, которые происходили в различные периоды истории, а отсюда понять их причинно-следственную связь.

В последующих записях Михаил Михайлович лишь мельком упоминает политические события в контексте бытовых вопросов. Например, 9 января Богословский пишет о том, что от Д. Н. Егорова узнал слухи о возможной забастовке на водоканале и предпо- 
Электронный научный журнал (Online). ISSN 2303-9922. http://www.vestospu.ru

ложил, что «подобное может быть 12-го в день предполагавшегося созвания Думы» [3, с. 290]. Основную часть времени января-февраля 1917 г. Михаил Михайлович уделяет работе над биографией Петра I, чтению книги П. В. Верховского об отношениях государства и церкви в период правления Петра I, рецензированию книги А. М. Гневушева об экономической и социальной жизни Новгорода в конце XV — начале XVI в. и чтению лекций на Богословских курсах. Заметим, что работа А. М. Гневушева профессору не понравилась, 17 января Богословский записал: «Все утро за книгой Гневушева, в которой открываю чудеса, побуждающие меня подумать, что она написана в пьяном виде» [3, c. 293]. Далее записи о чтении лекции в почти пустой аудитории Московского университета (5-10 слушателей), о поднятии жалованья до «ощутимой суммы» в 491 рубль в месяц и об отключении электричества и отсутствии в продаже свечей. Все эти факты свидетельствуют о том, что Богословский был активно «включен» в общественную жизнь 1917 г. Выполняя ежедневные, иногда рутинные «обязанности» ученого (например, написание рецензии), он вносил свою лепту в сохранение норм университетской жизни в новых социальных реалиях.

Однако если рассматривать происходящие события с позиции самого историка, основываясь на его саморефлексии, то основания для размышлений о «внутренней эмиграции» историка на страницах дневника все же встречаются. 13 февраля М. М. Богословский писал: «...я много раз ловлю себя на том, что прямо избегаю видеться с теми или другими и охотнее провожу время за книгой» [3, с. 306]. В тексте дневников, помимо описания бытовых, повседневных событий, историк периодически уходит в размышления, касающиеся жизни в целом, старения человека и скоротечности времени. В годовщину смерти отца Богословский написал: «Вот уже и для самого меня наступила старость и близость, естественная близость смерти. Почти четверть века пронеслась с быстротою вихря. Будем доживать остаток дней» [3, с. 304]. В марте 1917 г. Богословскому исполнилось 50 лет, это своего рода рубежный возраст, о чем он писал в дневнике: «Здравствуй - Старость!» [3, с. 328].

Следующая реакция на политические события возникает на страницах дневника почти сразу после отречения Николая II от престола. В дневнике Богословский пишет о монархии в контексте революции 1917 г. как о живом существе, именно поэтому 4 марта позволяет себе говорить именно о «смерти» монархии, а не о ее «свержении» или «ликвидации»: «Итак, монархия Божию милостью у нас кончилась, точно умерла <...> неотвязчивая тяжелая дума о будущем России все время владела мною и давила меня. Чувствовалось, что что-то давнее, историческое, крупное, умерло безвозвратно» [3, c. 319].

Важно, что далее по тексту историк вновь возвращается к размышлениям о будущем Российского государства и приходит к пессимистическим выводам о том, что Россия может оказаться в крайне невыгодном политическом положении на мировой арене: «К чему приводили перестройки государства по теориям, мы видим по примеру Франции в течение XIX века. Не дай нам Боже только последовать примеру польской республики!» [3, c. 319].

Уже 5 марта историк, продолжая формулировать прогнозы политического развития страны, сделал предположение о трансформации политического устройства страны от монархии к республике, а в июле сформулировал очень лаконичный, но красноречивый вывод: «Из абсолютной монархии прямо в “демократическую республику” не прыгают» $[3$, c. 396].

Общественно-политические события весны 1917 г. не могли оставить историка равнодушным, он считал необходимым высказаться по этому поводу. 8 марта Богословский 
Электронный научный журнал (Online). ISSN 2303-9922. http://www.vestospu.ru

сравнил текущую ситуацию с событиями реформации XVI века [3, с. 321]. Михаил Михайлович не принимал участия в работе политических партий и государственных органов, но, будучи историком, постоянно анализировал актуальные события настоящего в контексте мировой истории. Вообще для Богословского было свойственно сравнивать ситуацию в России 1917 г. с Европой XVI-XVII вв., сравнение не прямое, а скорее опосредованное, через сопоставление атмосферы и общественных настроений. Этот факт еще раз убеждает нас в ошибочности утверждения о «замыкании» и уходе историка во «внутреннюю эмиграцию».

Дальнейшие политические процессы затронули непосредственно М. М. Богословского. 12 марта 1917 г. в очередном выпуске «Русских ведомостей» в разделе «Последние известия» была опубликована новость об обсуждении на заседании Временного правительства представления А. А. Мануйлова об увольнении всех ординарных и экстраординарных профессоров, избранных на должности после 27 августа 1905 г. Список лиц, подлежащих увольнению, ректор университета был обязан в течение недели представить Мануйлову [17, с. 5]. М. М. Богословский болезненно отреагировал на эту новость: «Вот какие дела бывают на свете! Я вчера лег спать профессором Университета, а проснулся сегодня уже не профессором» [3, с. 324]. На страницах газеты еще несколько раз поднимался этот вопрос. Например, 15 марта был опубликован список профессоров, подлежащих «удалению» из университета, на историко-филологическом факультете таковых оказалось трое - А. А. Алмазов, И. И. Иванов и М. М. Богословский [18, с. 5]. В заметке отмечалось, что вопрос об увольнении профессоров остается открытым до появления циркуляра от министра народного просвещения, однако 21 марта Богословского окончательно уволили.

Заметим, что это политическое решение было неоднозначно встречено студентами. Современные исторические и социологические исследования отмечают, что в 1917 г. проблема «отцов и детей» проявлялась особенно резко в масштабах всего российского общества, на макроуровне. Однако на микроуровне ситуация выглядела несколько иначе. При общем конфликтном взаимоотношении поколений личностные взаимоотношения студентов и преподавателей оставались достаточно теплыми и уважительными. Уже 18 марта к М. М. Богословскому явились студенты филологического факультета с адресом в поддержку профессора, о чем через несколько дней сообщили «Русские ведомости» [16, с. 5], а 25 марта пришли молодые историки. Профессор был тронут вниманием со стороны студентов и в ответной речи, судя по дневниковым записям, проанализировал «типичную» судьбу русского профессора. По мнению Богословского, русскому профессору «редко удается пройти свою стезю мирно и беспрепятственно, не потерпев аварии сверху, снизу, справа или слева» [3, с. 334]. Последующее восстановление Богословского в должности профессора осталось незамеченным со стороны прессы, что задело самолюбие историка [3, с. 349].

Именно в моменте увольнения из Университета проявляются личностный выбор и индивидуальная траектория поведения историка в новой социокультурной обстановке. П. Н. Милюков и А. А. Кизеветтер после ухода из Университета все силы направили на политическую и партийную деятельность и добились там определенных успехов. В то же время М. М. Богословский ушел в профессиональную деятельность: писал статьи, рецензировал работы, продолжал читать лекции в Духовной академии и главное занимался написанием биографии Петра I. Именно отстранение от активного участия в политической жизни страны часто трактуется как проявление «внутренней эмиграции» историка.

Сравнение поведенческих траекторий П. Н. Милюкова, А. А. Кизеветтера и М. М. Богословского не случайно. Все три историка относятся к представителям московской 
Электронный научный журнал (Online). ISSN 2303-9922. http://www.vestospu.ru

исторической школы, близки по возрасту: П. Н. Милюков был старше Богословского на 8 лет, а А. А. Кизеветтер - на год. Все трое были учениками В. О. Ключевского, являлись представителями поколения историков конца XIX - начала XX века. Их профессиональное и личностное становление происходило в одной среде - Московском университете. Однако дальнейшие события в истории государства повлияли на формирование трех индивидуальных поведенческих стратегий. П. Н. Милюков, занявшись политикой в начале XX столетия, не возвращался в профессиональное историческое сообщество, А. А. Кизеветтер старался балансировать между деятельностью «политика» и «ученого»: был активным партийным деятелем, в то же время, вернувшись в Университет после ухода в 1911 г. по политическим причинам, продолжал академическую деятельность. М. М. Богословский избрал для себя крайнюю позицию - сохранение университетской и профессорско-преподавательской деятельности при отсутствии любой политической активности. Но сам факт сохранения места в Университете говорит если не о лояльности «новому государству», то как минимум о его принятии как новой исторической реальности.

Дальнейшие весенне-летние политические события в стране вызывают новую волну пессимизма. При этом заметим, что историк все чаще сравнивает происходящие события с процессами в истории государства XVI-XVII вв. Так, в начале апреля, после объявления некоторых украинских партий об автономии Украины, историк записал очень эмоциональный текст: «О Русская земля, собранная столькими трудами великорусского племени! Неужели ты начинаешь расползаться по своим еще не окончательно изгладившимся швам! Неужели нам быть опять Московским государством XVI в.!» [3, с. 338]. 21 апреля после «ноты Милюкова» и последовавшего конфликта между Советами и Временным правительством историк писал: «Мне временами кажется, что Россия обратилась в грандиозный сумасшедший дом, в необъятных размерах Бедлам, или, может быть, я теряю рассудок» [3, с. 346]. На наш взгляд, М. М. Богословский сознательно уклоняется от участия в общественно-политической жизни. Очевидно не поддерживая Советы и левые политические силы и называя Временное правительство «некоторым символом порядка» [3, с. 346], историк все же плохо ориентируется в политических силах. Так, 18 июля, критикуя узость и в некоторой степени ограниченность политических и исторических взглядов социалистов, Богословский называет лидера меньшевиков Ю. О. Мартова «большевиком-писакой» [3, с. 388].

Отношение к другим политическим лидерам 1917 г. также остается крайне негативным. А. А. Керенского Богословский называет «канатным плясуном», который передвигается «на задних лапках перед Советом рабочих и разных других депутатов» [3, с. 404]. В. И. Ленина - «немецким шпионом» и размышляет об истории самозванничества: «Россия в начале XVII в. видала единоличных самозванцев, в начале XX в. увидела самозванцев коллективных и столь же темных. За три века мы не исправились. У нас все то же тяготение к самозванщине» [3, с. 388].

Эмоционально переживая за будущее страны, но при этом не участвуя в политической деятельности, историк видит для себя выход в активной профессиональной деятельности. Именно на 1917 г. приходится написание главного труда — «Петр Великий: Материалы для биографии». Работа дает ему ощущение тишины и стабильности. М. М. Богословский 28 июля сделал следующую запись: «Для меня большая отрада, что я, работая, живу в 1697 г. в Голландии и таким образом хоть на несколько часов в день могу покидать русскую действительность XX века с ее “товарищами”, “эсерами”, “линиями поведения" и всем этим прочим словесным навозом и с ее небывалым позором» [3, c. 396]. Недовольство историка происходящими в настоящем времени событиями заставляет его все больше «убегать» в прошлое, погружаясь в тему исследования. Этот инди- 
Электронный научный журнал (Online). ISSN 2303-9922. http://www.vestospu.ru

видуальный выход имел положительные результаты и для самого М. М. Богословского, и для исторической науки в целом, поэтому его труд, несмотря на то что остался незаконченным, оказался одной из основных работ, посвященных биографии Петра I.

Осенние события 1917 г. вновь наталкивали М. М Богословского на проведение исторических параллелей и сравнений событий настоящего со Смутным временем. Размышляя о выступлении А. А. Керенского 24 октября на заседании Временного совета Российской республики и речи В. И. Ленина 25 октября на 2-м Всероссийском съезде Советов, на которых они обвинили друг друга в государственных преступлениях, Богословский вновь возвращается к истории Смутного времени: «Курьезно! Идет война двух государственных преступников. В Смутное время второй самозванец появился, когда погиб первый. Теперь второй самозванец согнал первого с престола» [3, с. 350]. Но самым главным, на наш взгляд, является вывод, к которому приходит М. М. Богословский: «В истории основное бывает сходно с различиями в частностях» [3, с. 350]. В этой фразе проявляется специфика профессионального взгляда историка на события 1917 г. Даже та отрывочная информация, которую Богословский получает из газет либо от коллег, позволяют ему абсолютно точно вписать 1917 г. в контекст мировой истории, выделить причинно-следственные связи происходящих процессов, а отсюда попытаться сделать предположения о том, по какому вектору будет развиваться государство в будущем.

25 октября 1917 г. историк записывает последние в уходящем году мысли, относящие к работе над биографией. Он отмечает, насколько ему комфортно заниматься историческим прошлым государства, «когда Россия проявляла свою бодрость и энергию». Продолжая сравнивать «старую» и «новую» Россию, М. М. Богословский вновь делает неутешительные выводы о настоящем, в некоторой степени идеализируя прошлое: «Это была не та дряблая, гнилая, пораженная неврастенией и разваливающаяся Россия, которую видим теперь» [3, с. 447].

Отметим, что М. М. Богословский в революционной ситуации выбрал индивидуальную траекторию, не похожую на ту, которую определили для себя некоторые его коллеги и современники. В отличие от П. Н. Милюкова и А. А. Кизеветтера, которые ушли в социально-политическую жизнь и впоследствии вынуждены были уехать, Богословский сумел, несмотря на внутреннее неприятие власти большевиков, успешно вписаться в контекст нового государства. Стратегию поведения историка можно назвать не «внутренней эмиграцией», а «мирным сосуществованием» с новой советской властью. Эта стратегия позволяла продолжить профессорско-преподавательскую деятельность, но при этом давала возможность в научных трудах сохранить «внутреннюю свободу».

В Советской России Богословский практически не подвергался репрессиям, 20 февраля 1923 г. и 11 декабря 1924 г. историка арестовывали, но причина ареста осталась неизвестной. М. М. Богословский продолжал преподавать в Московском университете, а затем стал профессором исторического отделения факультета общественных наук после преобразования Университета. В 1921 г. М. М. Богословский избран действительным членом Российской академии наук.

Таким образом, на основе анализа дневниковых записей историка за 1917 г. приходим к выводу о том, что вектор изучения жизни и деятельности М. М. Богословского может быть направлен и от настоящего к прошлому, и наоборот. Установлено, что не только социокультурный контекст и революционная повседневность 1917 г. повлияли на профессиональную деятельность и своего рода «закрытость» М. М. Богословского, что ранее справедливо отмечали С. О. Шмидт, А. В. Мельников и другие историки, но и, напротив, профессионализм Богословского позволил ему иначе воспринимать события революции 1917 г. На конкретных примерах мы выяснили, что Богословский в процессе 
Электронный научный журнал (Online). ISSN 2303-9922. http://www.vestospu.ru

анализа революционной повседневности постоянно возвращается к исторической аналогии, ассоциации и сопоставлению прошлого и настоящего. Причем ключевыми событиями, своего рода маркерами, отражающими характер революционных трансформаций, для историка становятся события Смутного времени в России XVII в., геополитическая деятельность Петра I, а также Английская революция XVII в. и Французская революция конца XVIII в. Именно сквозь призму этих событий М. М. Богословский рассматривал революцию 1917 г.

Историк в дневниковых записях рассуждал о настоящем через аналогии с прошлым. События прошлого стали для М. М. Богословского зеркалом, в котором преломлялись события общественно-политической жизни 1917 г. Его дневниковые записи свидетельствуют, что главным в процессе анализа событий, происходивших в то время, была идея преемственной связи между людьми прошлого и настоящего. Он постоянно возвращался к опыту жизни и деятельности людей прошлого, так как именно этот опыт служит связующим звеном между прошлым и настоящим. И сегодня тексты самого Богословского становятся источником для понимания событий прошлого.

\section{Список использованных источников и литературы}

1. Ахиезер А. С. Эмиграция из России: Культурно-исторический аспект // Свободная мысль. 1993. № 7. С. $70-78$.

2. Богословский М. М. Историография, мемуаристика, эпистолярия: (Научное наследие) / сост. Л. А. Черная ; отв. ред. А. И. Клибанов. М. : Наука, 1987. 214 с.

3. Богословский М. М. Дневники (1913-1919): Из собрания Государственного исторического музея / отв. ред. С. О. Шмидт. М. : Время, 2011. 800 с.

4. Воробьева О. В. «Между прошлым и настоящим»: типы дискурсов в творчестве А. Тойнби // История через личность: Историческая биография сегодня / под ред. Л. П. Репиной. М. : Квадрига, 2010. С. $369-389$.

5. Иванов А. Е. Михаил Богословский. Дневники. 1913-1919: Из собрания государственного исторического музея // Отечественные архивы. 2012. № 4. С. 109-111.

6. Кабытов П. С., Баринова Е. П. Драматическая рефлексия М. М. Богословского // Quaestio Rossica. 2018. Т. 6, № 4. С. 1217-1230.

7. Мельников А. В. К истории рукописи труда академика М. М. Богословского «Петр Великий: материалы для биографии»: предварительные археографические наблюдения // Богословский М. М. Петр Великий : материалы для биографии : в 6 т. / отв. ред. А. В. Мельников, С. О. Шмидт. М. : Наука, 2005. Т. 1. C. $432-477$.

8. Мельников А. В. М. М. Богословский в воспоминаниях современников // Археографический ежегодник за 2000 год. М. : Наука, 2001. С. 280-300.

9. Мельников А. В., Шмидт С. О. Мастера русской историографии: Михаил Михайлович Богословский (1867-1929) // Исторический архив. 2004. № 2. С. 119-134.

10. Неберекутина Е. В., Сафронова Т. В. Дневник М. М. Богословского // Археографический ежегодник за 2000 год. М. : Наука, 2001. С. 271-279.

11. Неберекутина Е. В., Сафронова Т. В. Из дневника академика М. М. Богословского // Вопросы истории. 2009. № 2. С. $91-111$.

12. Раев М. Россия за рубежом: История культуры русской эмиграции. 1919-1939. М. : ПрогрессАкадемия, 1994. 296 с.

13. Сидорова Л. А. Духовный мир историков «старой школы»: эмиграция внутренняя и внешняя. 1920-е годы // История и историки: историографический вестник. М., 2003. С. 168-191.

14. Сидорова Л. А. Советские историки: духовный и научный облик. М. : Ин-т российской истории PAH, 2017. 248 c.

15. Список печатных трудов академика М. М. Богословского (подготовил А. В. Мельников) // Археографический ежегодник за 1999 г. М. : Наука, 2000. С. 320-335.

16. Студенческая жизнь // Русские ведомости. 1917. № 65.

17. Увольнение назначенных профессоров // Русские ведомости. 1917. № 57.

18. Увольняемые профессора // Русские ведомости. 1917. № 59. 
Электронный научный журнал (Online). ISSN 2303-9922. http://www.vestospu.ru

19. Халина Т. И. Богословский Михаил Михайлович // Историки России: Биографии / отв. ред. А. А. Чернобаев. М. : РОССПЭН, 2001. С. 426-433.

20. Халина Т. И. В науке приятно быть и простым чернорабочим: Михаил Михайлович Богословский // Историки России: XVIII — начало XX века / отв. ред. А. Н. Сахаров. М. : Скрипторий, 1996. С. 658 - 685.

21. Черепнин Л. В. Академик М. М. Богословский // Исторические записки. 1974. Т. 93. С. $223-271$.

22. Шмидт С. О. Многотомное исследование академика М. М. Богословского «Петр Великий: Материалы для биографии» // Богословский М. М. Петр Великий: Материалы для биографии : в 6 т. / отв. ред. С. О. Шмидт. М. : Наука, 2005. Т. 1. С. 414-431.

23. Шмидт С. О. Образ истории в дневнике московского историка М. М. Богословского (19151917 гг.) // Достоинство историка / отв. ред. В. А. Тишков ; сост. В. Б. Жиромская. М. : РОССПЭН, 2011. С. $64-79$.

24. Шмидт С. О. Дневник московского историка и его особенности // Богословский М. М. Дневники (1913-1919): Из собрания Государственного исторического музея / отв. ред. С. О. Шмидт. М. : Время, 2011. C. $5-52$.

Поступила в редакцию 09.08.2019

Серых Анна Александровна, кандидат исторических наук

Самарский государственный технический университет

Российская Федерация, 443100, г. Самара, ул. Молодогвардейская, 244

E-mail: serykha@mail.com

\section{UDC 94(47)“1917”}

\section{A. A. Serykh}

\section{The past and present in the revolutionary everyday life of M. M. Bogoslovsky (based on materials from the historian's diary)}

The article analyzes the diary entries of the professor of the Moscow Imperial University M. M. Bogoslovsky in 1917. The concept of "internal emigration" is questioned in relation to the strategy of his behavior. The features of the theological perception of the revolutionary everyday life of 1917 are determined through the prism of the historian's professional experience. The historical events of Russian and world history are revealed, which Bogoslovsky considered the markers, determining the nature of the revolutionary transformations of 1917. It is concluded that the professional historical view of M. M. Bogoslovsky on the 1917 revolution allowed him to include revolutionary events in the context of world and national history and put them on a par with the events of the Time of Troubles in Russia, as well as with the English and French revolutions. It is through a comparison of the 1917 revolution with significant historical events that the historian on the pages of the diary comes to pessimistic forecasts about the future of the Russian state. Through the analysis of diary entries, the author of the article revealed the theological significance of a continuum between the life experience in the past and the present, since it is the historical experience, in his opinion, that is the connecting link in history.

Key words: diary entries, M. M. Bogoslovsky, “internal emigration”, Russian Empire, 1917 revolution.

Serykh Anna Aleksandrovna, Candidate of Historical Sciences

Samara State Technical University

Russian Federation, 443100, Samara, ul. Molodogvardeiskaya, 244

Email: serykha@mail.com

\section{References}

1. Akhiezer A. S. Emigratsiya iz Rossii: Kul'turno-istoricheskii aspekt [Emigration from Russia: Cultural and Historical Aspect]. Svobodnaya mysl', 1993, no. 7, pp. 70_-78. (In Russian)

2. Bogoslovskii M. M. Istoriografiya, memuaristika, epistolyariya: (Nauchnoe nasledie) [Historiography, memoirs, epistolary: (Scientific heritage)]. Moscow, Nauka Publ., 1987. 214 p. (In Russian) 


\section{Электронный научный журнал (Online). ISSN 2303-9922. http://www.vestospu.ru}

3. Bogoslovskii M. M. Dnevniki (1913-1919): Iz sobraniya Gosudarstvennogo istoricheskogo muzeya [Diaries (1913-1919): From the collection of the State Historical Museum]. Moscow, Vremya Publ., 2011. 800 p. (In Russian)

4. Vorob'eva O. V. "Mezhdu proshlym i nastoyashchim": tipy diskursov v tvorchestve A. Toinbi ["Between the Past and the Present": Types of Discourses in A. Toynbee's Works]. Istoriya cherez lichnost': Istoricheskaya biografiya segodnya [History through a Person: A Historical Biography Today]. Moscow, Kvadriga Publ., 2010, pp. 369-389. (In Russian)

5. Ivanov A. E. Mikhail Bogoslovskii. Dnevniki. 1913 - 1919: Iz sobraniya gosudarstvennogo istoricheskogo muzeya [Mikhail Bogoslovsky. Diaries. 1913-1919: From the collection of the State Historical Museum]. Otechestvennye arkhivy, 2012, no. 4, pp. 109-111. (In Russian)

6. Kabytov P. S., Barinova E. P. Dramaticheskaya refleksiya M. M. Bogoslovskogo [Bogoslovsky’s Dramatic Reflection]. Quaestio Rossica, 2018, vol. 6, no. 4, pp. 1217-1230. (In Russian)

7. Mel'nikov A. V. K istorii rukopisi truda akademika M. M. Bogoslovskogo "Petr Velikii: materialy dlya biografii": predvaritel'nye arkheograficheskie nablyudeniya [On the history of the manuscript of academician M. M. Bogoslovsky's work "Peter the Great: materials for biography": preliminary archaeographic observations]. Bogoslovskii M. M. Petr Velikii: materialy dlya biografii: v $6 t$. [Bogoslovsky M. M. Peter the Great. Materials for biography. In 6 volumes]. Moscow, Nauka Publ., 2005, vol. 1, pp. 432 - 477. (In Russian)

8. Mel'nikov A. V. M. M. Bogoslovskii v vospominaniyakh sovremennikov [M. M. Bogoslovsky in the memoirs of contemporaries]. Arkheograficheskii ezhegodnik za 2000 god [Archaeographic Yearbook for 2000]. Moscow, Nauka Publ., 2001, pp. 280-300. (In Russian)

9. Mel'nikov A. V., Shmidt S. O. Mastera russkoi istoriografii: Mikhail Mikhailovich Bogoslovskii (18671929) [Masters of Russian historiography: Mikhail Mikhailovich Bogoslovsky (1867-1929)]. Istoricheskii arkhiv, 2004, no. 2, p. 119-134. (In Russian)

10. Neberekutina E. V., Safronova T. V. Dnevnik M. M. Bogoslovskogo [Diary of M. M. Bogoslovsky]. Arkheograficheskii ezhegodnik za 2000 god [Archaeographic Yearbook for 2000]. Moscow, Nauka Publ., 2001, pp. 271-279. (In Russian)

11. Neberekutina E. V., Safronova T. V. Iz dnevnika akademika M. M. Bogoslovskogo [From the diary of academician M. M. Bogoslovsky]. Voprosy istorii, 2009, no. 2, pp. 91-111. (In Russian)

12. Raev M. Rossiya za rubezhom: Istoriya kultury russkoi emigratsii. 1919-1939 [Russia Abroad: A History of the Culture of Russian Emigration. 1919-1939]. Moscow, Progress-Akademiya Publ., 1994. 296 p. (In Russian)

13. Sidorova L. A. Dukhovnyi mir istorikov "staroi shkoly": emigratsiya vnutrennyaya i vneshnyaya. 1920-e gody [The spiritual world of the historians of the "old school": emigration is internal and external. 1920s]. Istoriya i istoriki: istoriograficheskii vestnik [History and historians: a historiographic bulletin]. Moscow, 2003, pp. 168-191. (In Russian)

14. Sidorova L. A. Sovetskie istoriki: dukhovnyi i nauchnyi oblik [Soviet historians: spiritual and scientific appearance]. Moscow, In-t rossiiskoi istorii RAN Publ., 2017. 248 p. (In Russian)

15. Spisok pechatnykh trudov akademika M. M. Bogoslovskogo (podgotovil A. V. Mel'nikov) [List of printed works of Academician M. M. Bogoslovsky (prepared by A. V. Melnikov)]. Arkheograficheskii ezhegodnik za 1999 g. [Archaeographic Yearbook for 1999]. Moscow, Nauka Publ., 2000, pp. 320-335. (In Russian)

16. Studencheskaya zhizn' [Student life]. Russkie vedomosti, 1917, no. 65. (In Russian)

17. Uvol'nenie naznachennykh professorov [Dismissal of appointed professors]. Russkie vedomosti, 1917, no. 57. (In Russian)

18. Uvol'nyaemye professora [Dismissed professors]. Russkie vedomosti, 1917, no. 59. (In Russian)

19. Khalina T. I. Bogoslovskii Mikhail Mikhailovich [Bogoslovsky Mikhail Mikhailovich]. Istoriki Rossii: Biografii [Historians of Russia. Biographies]. Moscow, ROSSPEN Publ., 2001, pp. 426 - 433. (In Russian)

20. Khalina T. I. V nauke priyatno byt' i prostym chernorabochim: Mikhail Mikhailovich Bogoslovskii [It's nice to be a simple laborer in science: Mikhail Mikhailovich Bogoslovsky]. Istoriki Rossii: XVIII - nachalo XX veka [Historians of Russia: XVIII — early XX century]. Moscow, Skriptorii Publ., 1996, pp. 658 - 685. (In Russian)

21. Cherepnin L. V. Akademik M. M. Bogoslovskii [Academician M. M. Bogoslovsky]. Istoricheskie zapiski - Historical Notes, 1974, vol. 93, pp. 223-271. (In Russian)

22. Shmidt S. O. Mnogotomnoe issledovanie akademika M. M. Bogoslovskogo "Petr Velikii: materialy dlya biografii" [Multivolume study by Academician M. M. Bogoslovsky "Peter the Great: materials for biography"]. Bogoslovskii M. M. Petr Velikii: materialy dlya biografii: v 6 t. [Bogoslovsky M. M. Peter the Great. Materials for biography. In 6 volumes]. Moscow, Nauka Publ., 2005, vol. 1, pp. 414-431. (In Russian) 
Электронный научный журнал (Online). ISSN 2303-9922. http://www.vestospu.ru

23. Shmidt S. O. Obraz istorii v dnevnike moskovskogo istorika M. M. Bogoslovskogo (1915—1917 gg.) [The image of history in the diary of the Moscow historian M. M. Bogoslovsky (1915-1917)]. Dostoinstvo istorika [Dignity of the historian]. Moscow, ROSSPEN Publ., 2011, pp. 64-79. (In Russian)

24. Shmidt S. O. Dnevnik moskovskogo istorika i ego osobennosti [The diary of a Moscow historian and its features]. Bogoslovskii M. M. Dnevniki (1913-1919): Iz sobraniya Gosudarstvennogo istoricheskogo muzeya [Bogoslovsky M. M. Diaries (1913-1919): From the collection of the State Historical Museum]. Moscow, Vremya Publ., 2011, pp. 5-52. (In Russian) 